\title{
SITING OF NUCLEAR POWER STATIONS
}

$I^{\mathrm{N}}$ $\mathrm{N}$ a debate on the siting of nuclear power stations initiated in the House of Commons on December 19 by Mr. A. Blenkinsop and Mr. T. W. Jones, the Parliamentary Secretary to the Ministry of Power, Mr. D. Renton declined to comment on the project for a nuclear power station in Merioneth because the Minister had already decided to hold an inquiry ; but he gave a full account of the procedure for preserving the amenities of the countryside so far as the Ministry of Power is concerned which was distinctly reassuring. Mr. Renton recognized the serious conflict and dilemma which arises, and assured the House that the limited possibilities of using land already developed or waste were not overlooked. In selecting the four sites already chosen and in choosing the remaining eight before the end of 1966, a preliminary general suggestion by the Central Electricity Authority is followed in each case by the search for a particular site by the Authority, and then by application to the Minister of Power, usually with a public inquiry before the Minister gave his decision.

Throughout the three stages there are certain limiting factors. First is the purely economic one, requiring nuclear power stations to be sited where the greatest economic benefit may be securedin regions where the cost of cosl is highest, remote from coalfields. Second are safety considerations, and the Government is adhering to the policy of avoiding built-up areas. Furthermore, such power stations require large quantities of cooling water, as much as 35 million gallons an hour for the stations now contemplated, solid foundations for the very heavy buildings and plant, and an area of about 300 acres.

It is with these considerations in mind that the Central Electricity Board-and from January 1, 1958, the Central Electricity Generating Board-make preliminary studies in each area where a power station appears to be needed. These studies include a thorough consideration of the development plans of local planning authorities, of the maps of the national parks and areas of outstanding natural beauty, both of which must be avoided if possible, and a geographical study of basic physical features, such as water supplies. On the basis of these general studies, the team of technical experts of the Authority proceed to what they call site selection. This may take three to twelve months, involving consideration of every possible site in the area of search and sometimes survey before provisional selection. Besides the local planning authority, the Ministry of Housing and
Locel Government, the Ministry of Agriculture, the Home Office, the Air Ministry, the Ministry of Transport and Civil Aviation, if necessary the Admiralty and the War Office, the National Parks Commission and the Nature Conservancy are consulted and, after a site has been provisionally selected, the Royal Fine Art Commission. Moreover, Mr. Renton pointed out, under Section 37 of the Electricity Act, the Board, the Electricity Council and the Minister of Power must have regard "to the desirability of preserving natural beauty, of conserving flora, fauna and geological or physiographical features of special interest, and of protecting buildings and other objects of architectural or historical interest".

They must take into account the effect of their proposals on the natural beauty of the countryside and on any such flora, fauna, features, buildings and objects. Furthermore, it is not until these studies and consultations are completed that formal application is made to the Minister for his consent. When the Minister receives such an application he is now obliged to hold a public inquiry whenever a local planning authority objects and he may do so when there is any other objection. In such an inquiry he receives expert advice from his Ministry's inspector, who sometimes sits with an inspector of the Ministry of Housing and Local Government.

Observing that a conflict of public interests could only be resolved by a Minister or Ministers, Mr. Renton said that the aim was to provide a flexible system of planning. Each planning authority had the duty of formulating a county development plan and the Minister of Housing and Locel Government has certain statutory duties in respect of development plans. $\mathrm{He}$ and other Ministers concerned were consulted by the Minister of Power before he gave his decision on each application, and the Minister's decision, which was that of the Government, could be questioned in Parliament. Mr. Renton said that the Minister of Housing and Local Government had overall responsibility for preserving amenities under the Planning Acts and his Ministry provided the information, maps and detailed plans which helped to prevent any avoidable desecration of the besuties of the countryside. Mr. Renton did not think that the central consultative committee of amenity associations suggested by Mr. Blenkinsop would contribute anything further, and he thought there was already sufficient frequent consultation with the National Parks Commission from the inception of any scheme.

\section{CONCRETE ROADS}

$\mathrm{A}^{\mathrm{N}}$ $\mathrm{N}$ international congress was held in Rome in October to discuss recent technical progress and achievements in the construction of concrete roads and runways. Seventeen lectures were given by prominent engineers from ten countries and reports on the sub. jects to be discussed were also received from many others. About 800 delegates from 28 countries attended.

The congress enabled the practice in different countries to be compared, and it was of particular interest to note where there was general agreement and where there were differences. It was generally agreed that motorways and urban expressways were desirable on grounds of economy and safety. Most countries, and in particular Western Germany and Holland which together contain 80 per cent of the motorways existing in Western Europe, have preferred concrete construction for motorways. The slab thicknesses used in most countries were comparable and were based on experience; the thick- 